\title{
A novel GATA4 mutation completely segregated with atrial septal defect in a large Japanese family
}

\author{
A Okubo, O Miyoshi, K Baba, M Takagi, K Tsukamoto, A Kinoshita, K Yoshiura, T Kishino, T Ohta, \\ N Niikawa, N Matsumoto
}

J Med Genet 2004;41:e97 (http://www.jmedgenet.com/cgi/content/full/41/7/e97). doi: 10.1136/jmg.2004.018895

A trial septal defect (ASD) is characterised by left-toright shunting and increased right ventricular output. ${ }^{1}$ Approximately $5-10 \%$ of congenital heart diseases (CHD) are due to ASD which is one of the most frequent CHD found in human adults. ${ }^{2}$ ASD has been presumed to be caused by genetic factors. ${ }^{3}$ Recently, a few genes have been implicated in syndromic and non-syndromic ASD. Mutations in T-BOX5 at $12 \mathrm{q} 24.1,{ }^{5}{ }^{6} \mathrm{NKX} 2.5$ at $5 \mathrm{q} 34,{ }^{78} \mathrm{EVC}$ at $4 \mathrm{pl} 6.1,{ }^{9}$ and GATA4 at $8 \mathrm{p} 23.1-\mathrm{p} 22^{10}$ cause Holt-Oram syndrome with ASD or ventricular septal defect (VSD), non-syndromic CHD including ASD and atrioventricular conduction abnormalities, Ellis-van Creveld syndrome with ASD, and a familial isolated ASD, respectively.

We encountered a large family of four generations where 11 members were affected with ASD, and where disease transmission was consistent with an autosomal dominant mode of inheritance. Here we report a novel mutation of GATA4 in this family.

\section{METHODS \\ Subjects}

A large Japanese family composed of a total of 29 members across four generations contained 11 members with ASD (I- 1 , II-2, II-6, II-7, III-1, III-2, III-4, IV-1, IV-2, IV-5, and IV-6; fig 1A). ASD in five patients (II-7, III-1, III-2, IV-1, and IV-2) was surgically repaired, and two patients (II-2 and IV-1) also had pulmonary stenosis (PS). The heart defects in eight subjects (II-2, II-7, III-1, III-2, IV-1, and IV-2) including two diseased subjects (I-1 and II-6) had been clinically diagnosed by one of co-authors (BK) on the basis of their past histories, operation records, 12-lead electrocardiograms, and echocardiograms with colour Doppler apparatus (fig 1A), while those in three other subjects (III-4, IV-5, and IV-6) were retrospectively found using information provided by the mutation analysis described below. None of the 11 affected members had any other abnormalities in the cardiac conduction system or other organs. After informed consent was obtained, DNA was extracted from peripheral blood leukocytes of 22 family members.

\section{Linkage and mutation analyses}

Linkage analysis was performed in 22 family members at 11 microsatellite marker loci around GATA4 at 8p23 (D8S561, D8S503, D8S1721，D8S550，D8S265, D8S552, D8S1790, D8S549, D8S254, D8S258, and D8S1771), and two-point linkage analysis was carried out using the computer program MLINK (FASTLINK software, version 4.1P), as described previously. ${ }^{11}$ III-4, IV-5, and IV-6 were regarded as unaffected at this initial linkage analysis.

All exons in the 22 members covering the coding region of GATA4 were then amplified by PCR. PCR and sequencing primers are shown in table 1 . PCR was cycled 35 times at $98^{\circ} \mathrm{C}$ for $30 \mathrm{~s}, 55-58^{\circ} \mathrm{C}$ for $30 \mathrm{~s}, 72^{\circ} \mathrm{C}$ for $1 \mathrm{~min}$ in a $25 \mu \mathrm{l}$ mixture containing $1 \times$ ThermalAce Buffer (or $1 \times$ Ex Taq

\section{Key points}

- Linkage analysis in a large Japanese family with atrial septal defect (ASD) suggested GATA4 as a possible candidate gene for heart disease.

- Mutation analysis of GATA4 identified a novel $1 \mathrm{bp}$ deletion (c.1074delC) at exon 6 in all nine family members with ASD, but not in the family members without the disease.

- This is the second report linking GATA4 mutation with an isolated congenital heart defect.

Buffer (Takara, Ohtsu, Japan)), $0.2 \mathrm{mM}$ each dNTP, $0.5 \mu \mathrm{M}$ each primer, and $1 \mathrm{U}$ ThermalAce DNA polymerase (Invitrogen, Carlsbad, USA) (or $0.5 \mathrm{U}$ TaKaRa Ex Taq ${ }^{\mathrm{TM}}$ DNA polymerase (TaKaRa)). PCR products were purified using ExoSap-IT (USB, OH, USA) and sequenced by a standard protocol using BigDye Terminator (Applied Biosystems, Foster City, CA, USA) on an ABI PRISM 3100 Genetic Analyzer (Applied Biosystems). GATA4 sequences of affected members were compared with those of normal controls using Autoassembler 2.1 (Applied Biosystems).

\section{RESULTS AND DISCUSSION}

Linkage analysis gave a maximum LOD score of 1.61 (recombination fraction $(\theta)=0$, penetrance $=0.65$ ) at D8S552 on 8p23.1-p22, the findings suggesting GATA4 as a possible candidate gene for ASD in this family. The sequence analysis revealed that nine (II-2, II-7, III- 1, III-2, III-4, IV-1, IV-2, IV-5, and IV-6) of the 22 members had a heterozygous 1 bp deletion (c.1074delC) at exon 6 of GATA4 (fig 1B). The $1 \mathrm{bp}$ deletion results in a frame shift and is predicted to create a premature stop codon at amino acid 403, leading to protein truncation (fig $1 \mathrm{C}$ ). The mutation was never observed in 13 unaffected members of the family or in 100 normal controls.

Early and precise diagnosis of ASD is clinically important, because leaving it uncorrected until adulthood may result in right heart failure, although some patients with minor ASD can often lead a healthy life. As the mortality rate of ASD operations is very low in patients without cardiac failure under the age of $45,{ }^{1}$ early surgical intervention is feasible. Clinical re-evaluation of three members (III-4, IV-5, and IV-6) who were previously thought to be unaffected confirmed their disease. Thus, penetrance in the pedigree we describe is actually complete. This information will be very

Abbreviations: $A S D$, atrial septal defect; $C H D$, congenital heart diseases; PS, pulmonary stenosis; TOF, tetralogy of Fallot; VSD, ventricular septal defect 
A

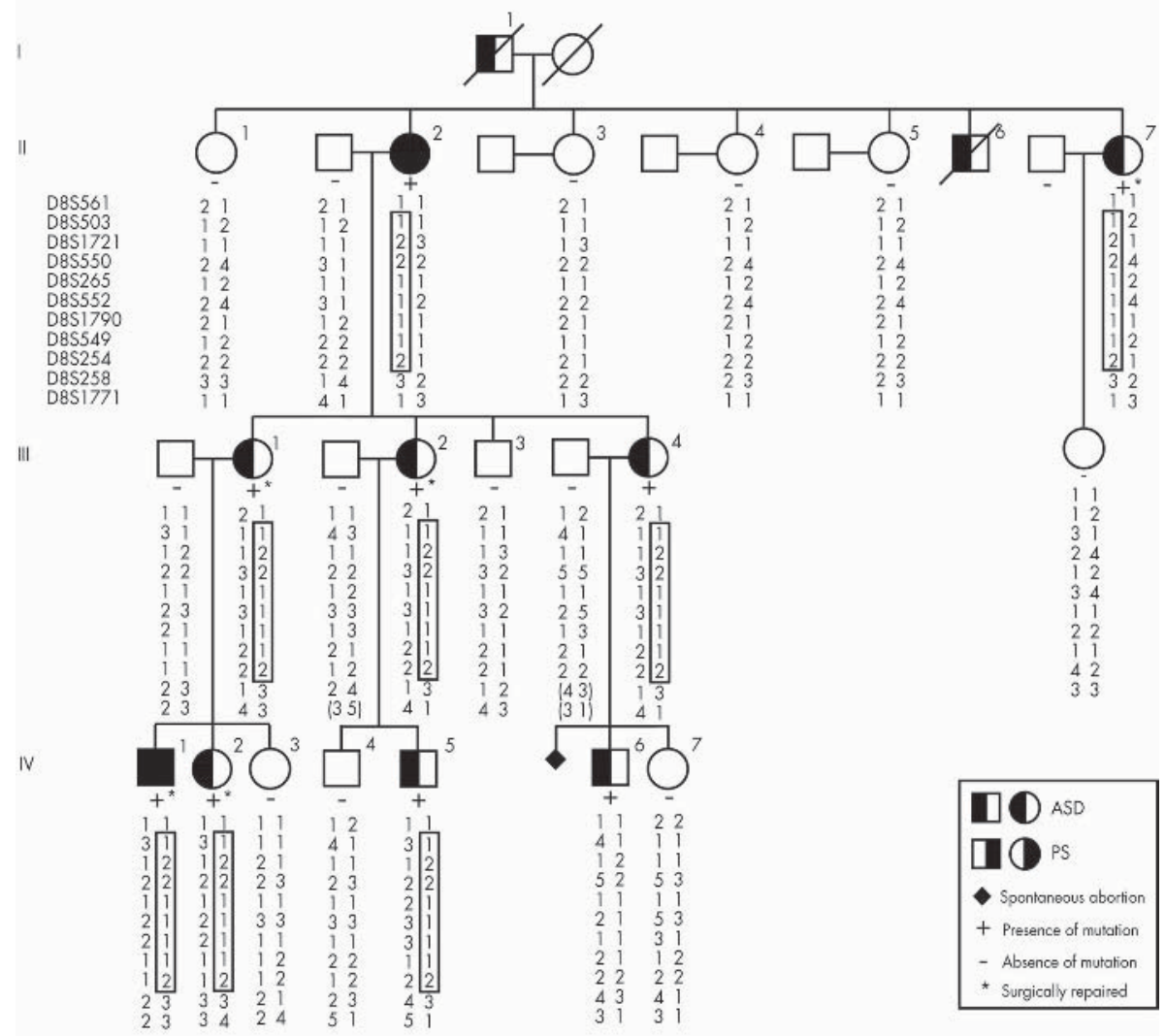

B

C
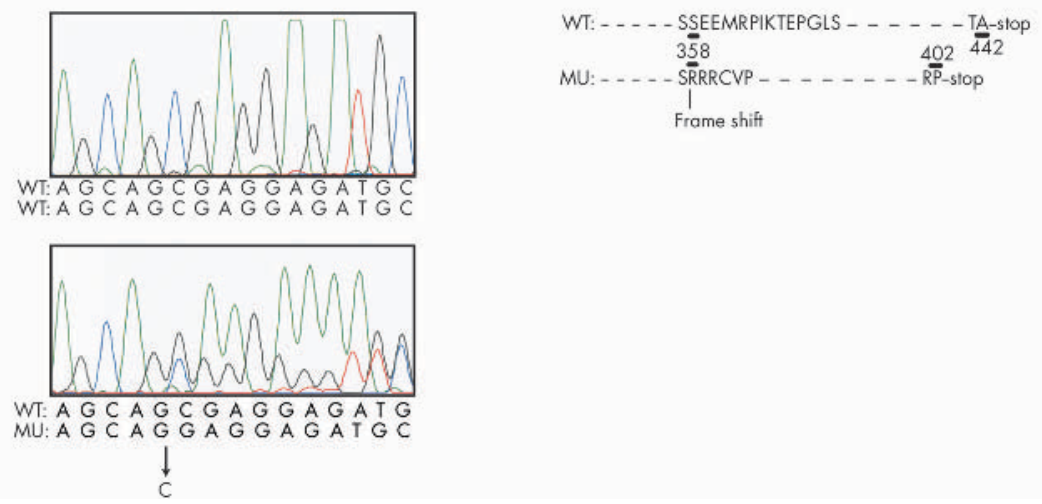

Figure 1 (A) Pedigree of a large Japanese family with heart defects, haplotypes at marker loci on chromosome 8, and GATA4 mutation. ASD was observed in 11 members and PS in two. A common haplotype associated with ASD at eight marker loci, D8S503, D8S1721, D8S550, D8S265, D8S552, D8S1790, D8S549, and D8S254, was boxed. All members with the heart defects had a GATA4 mutation, c. 1074delC.

(B) Electropherogram of an unaffected family member with wild type alleles of GATA4 (upper), and an affected member heterozygous for a mutated allele, c. 1074del, at exon 6 of GATA4 (lower). (C) Wild type (WT) and mutated (MU) amino acid sequences of GATA4 protein. The c. 1074del causes a frame shift and creates a premature stop codon at amino acid 403.

useful for genetic counselling for this family, because testing for c.1074delC in new family members can be followed by careful medical examination and prophylactic intervention if ASD is found. Revised linkage analysis using information from newly confirmed patients (III-4, IV-5, and IV-6) provided a maximum LOD score of 4.43 (recombination fraction $(\theta)=0$, penetrance $=0.95$ ) at D8S552.

ASD in two patients with the mutation in our family was associated with PS. A similar finding has been reported in two families with GATA4 mutations by Garg et $a^{10}$ : one family (family B) had isolated ASD and a deletion mutation, c.1075delG, while the other (family A) presented with complex heart defects such as atrioventricular septal defect, PS, aortic regurgitation, patent ductus arteriosus in addition to ASD, and a missense mutation, c.886 G>A (G296S). The missense mutation, c. $886 \mathrm{G}>\mathrm{A}$, disturbed the interaction between GATA4 and TBX5. ${ }^{10}$ TBX5 and NKX2-5 mutations can cause Holt-Oram syndrome with tetralogy of Fallot (TOF) 
Table 1 PCR primer sequences

\begin{tabular}{|c|c|c|c|}
\hline Exon & Forward $\left(5^{\prime}-3^{\prime}\right)$ & Reverse $\left(5^{\prime}-3^{\prime}\right)$ & Product size (bp) \\
\hline 1 & AGACCCCAGAGCCTGGACTT & GCAAAGTCAAAAGCAGAGCA & 448 \\
\hline $2-1$ & AACGCCTGGACAAAACAAAG & CCAAGCTCTGATACATGGTC & 652 \\
\hline $2-2$ & CAGTTCCTCCCACGCATATT & СTTCTGCCTTCCCTAGAAAC & 872 \\
\hline 3 & AAAGGGCATGTTCTGTGC & GATGCACACCCTCAAGTTC & 377 \\
\hline 4 & GGGCAGTGCACACCTITTAC & GAGAGATGGGCATCAGAAGG & 232 \\
\hline 5 & GCTTAGGTGTTGCCTTCTCG & TGCCTAACCCGGAAGATATG & 270 \\
\hline 6 & ACTGTAGCCCTCCGCAGATA & TGAGGCCTGGCTGCAAGTC & 404 \\
\hline $7-1$ & ACATCTGCATAGCAGGGCAC & TGCCATGCCTCAAGCGGAT & 755 \\
\hline $7-2$ & CGAGGATCTGAGAACAAGCG & CGTGTTGCAGAATCTCTGGC & 755 \\
\hline $7-3$ & GCTCAAGCCAGTCTGGCAAG & AGTGGGTCAGTGCCTACACG & 755 \\
\hline
\end{tabular}

and non-syndromic TOF, respectively. ${ }^{5}{ }^{12}$. TOF includes PS. As GATA4 functionally interacts with TBX5 and NKX2$5,^{1014} 15$ the c.1074delC in the family we described may disturb the coordinated interaction between GATA4 and TBX5 or NKX2-5 in cardiogenesis, resulting in PS in the two affected members of our family. It is also noted that the truncated protein generated by the c.1074delC is very similar to that generated by the c.1075delG except for a serine residue. It is likely that the c.1074delC is unable to activate transcription of downstream genes, being similar to the c. $1075 \mathrm{delG}$ as reported by Garg et al..$^{10}$ In summary, the GATA4 c.1074delC likely results in haploinsufficiency, and causes a cardiac phenotype similar to that described in $8 p$ deletion syndrome. ${ }^{16}$ In addition, a syndromic PS associated with Noonan/LEOPARD syndrome and Alagille syndrome has been shown to be caused by mutations of PTPNIl at $12 \mathrm{q} 22^{17} 18$ and $J A G 1$ at $20 \mathrm{pl} 2,{ }^{19}{ }^{20}$ respectively. JAGl mutation can also result in isolated PS. ${ }^{21}$ It might be interesting to investigate the relationship between GATA4 and PTPNIl or JAGl.

In conclusion, we identified a 1 bp deletion of GATA4 in a large Japanese family with ASD. Segregation of ASD with the GATA4 mutation with complete penetrance in this family suggests that one type of ASD is caused by a single gene defect. It remains to be seen how much GATA4 mutations contribute to the pathogenesis of congenital heart defects in man.

\section{Authors' affiliations}

A Okubo, O Miyoshi, A Kinoshita, K Yoshiura, N Niikawa,

N Matsumoto, Department of Human Genetics, Nagasaki University Graduate School of Biomedical Sciences, Nagasaki, Japan

A Okubo, K Tsukamoto, Department of Clinical Pharmacy, Nagasaki University Graduate School of Biomedical Sciences, Nagasaki, Japan O Miyoshi, Department of Psychiatry, Mie University School of Medicine, Tsu, Japan

K Baba, Baba Clinic, Nagasaki, Japan

M Takagi, Joseph Clinic, Nagasaki, Japan

A Kinoshita, K Yoshiura, T Kishino, T Ohta, N Niikawa, N Matsumoto, CREST, Japan Science and Technology Agency, Kawaguchi, Japan

T Kishino, T Ohta, Division of Functional Genomics, Center for Frontier Life Sciences, Nagasaki University, Nagasaki, Japan N Matsumoto, Department of Human Genetics, Yokohama City University Graduate School of Medicine, Yokohama, Japan Conflict of interest: none declared.

Correspondence to: Dr N Matsumoto, Department of Human Genetics, Yokohama City University Graduate School of Medicine, Fukuura 3-9, Kanazawa-ku, Yokohama 236-0004, Japan; naomat@

yokohama-cu.ac.jp

Received 28 January 2004

Accepted for publication 24 February 2004

\section{REFERENCES}

1 Tierney LM. Current medical diagnosis and treatment, 40th ed. New York: McGraw-Hill, 2001.

2 Hoffman Jl. Congenital heart disease: incidence and inheritance. Pediatr Clin North Am 1990;37:25-43.

3 Ferencz C, Boughman JA, Neill CA, Brenner JI, Perry LW. Congenital cardiovascular malformations: questions on inheritance. BaltimoreWashington Infant Study Group. J Am Coll Cardiol 1989;14:756-63.

4 Benson DW, Sharkey A, Fatkin D, Lang P, Basson CT, McDonough B, Strauss AW, Seidman JG, Seidman CE. Reduced penetrance, variable expressivity, and genetic heterogeneity of familial atrial septal defects. Circulation 1998:97:2043-8.

5 Li QY, Newbury-Ecob RA, Terrett JA, Wilson DI, Curtis AR, Yi CH, Gebuhr T, Bullen PJ, Robson SC, Strachan T, Bonnet D, Lyonnet S, Young ID Raeburn JA, Buckler AJ, Law DJ, Brook JD. Holt-Oram syndrome is caused by mutations in TBX5, a member of the Brachyury (T) gene family. Nat Genet 1997; 15:21-9.

6 Fan C, Duhagon MA, Oberti C, Chen S, Hiroi Y, Komuro I, Duhagon PI, Canessa R, Wang Q. Novel TBX5 mutations and molecular mechanism for Holt-Oram syndrome. J Med Genet 2003;40:e29.

7 Schott JJ, Benson DW, Basson CT, Pease W, Silberbach GM, Moak JP Maron BJ, Seidman CE, Seidman JG. Congenital heart disease caused by mutations in the transcription factor NKX2-5. Science 1998;281:108-11.

8 Benson DW, Silberbach GM, Kavanaugh-McHugh A, Cottrill C, Zhang Y, Riggs S, Smalls O, Johnson MC, Watson MS, Seidman JG, Seidman CE, Plowden J, Kugler JD. Mutations in the cardiac transcription factor NKX2.5 affect diverse cardiac developmental pathways. J Clin Invest 1999; 104:1567-73.

9 Ruiz-Perez VL, Ide SE, Strom TM, Lorenz B, Wilson D, Woods K, King L, Francomano C, Freisinger P, Spranger S, Marino B, Dallapiccola B, Wright M Meitinger T, Polymeropoulos MH, Goodship J. Mutations in a new gene in Ellis-van Creveld syndrome and Weyers acrodental dysostosis. Nat Genet 2000;24:283-6.

10 Garg V, Kathiriya IS, Barnes R, Schluterman MK, King IN, Butler CA, Rothrock CR, Eapen RS, Hirayama-Yamada K, Joo K, Matsuoka R, Cohen JC, Srivastava D. GATA4 mutations cause human congenital heart defects and reveal an interaction with TBX5. Nature 2003:424:443-7.

11 Komatsu K, Nakamura N, Ghadami M, Matsumoto N, Kishino T, Ohta T, Niikawa N, Yoshiura K. Confirmation of genetic homogeneity of nonsyndromic low-frequency sensorineural hearing loss by linkage analysis and a DFNA6/14 mutation in a Japanese family. J Hum Genet 2002;47:395-9

12 McElhinney DB, Geiger E, Blinder J, Woodrow Benson D, Goldmuntz E. NKX2.5 mutations in patients with congenital heart disease. J Am Coll Cardiol 2003:42:1650-5

13 Goldmuntz E, Geiger E, Benson DW. NKX2.5 mutations in patients with tetralogy of Fallot. Circulation 2001;104:2565-8.

14 Sepulveda JL, Vlahopoulos S, lyer D, Belaguli N, Schwartz RJ. Combinatoria expression of GATA4, Nkx2-5, and serum response factor directs early cardiac gene activity. J Biol Chem 2002;277:25775-82.

15 Durocher D, Charron F, Warren R, Schwartz RJ, Nemer M. The cardiac transcription factors $\mathrm{Nkx2-5}$ and GATA-4 are mutual cofactors. EMBO 1997: 16:5687-96.

16 Pehlivan T, Pober BR, Brueckner M, Garrett S, Slaugh R, Van Rheeden R, Wilson DB, Watson MS, Hing AV. GATA4 haploinsufficiency in patients with interstitial deletion of chromosome region 8 p23.1 and congenital heart disease. Am J Med Genet 1999;83:201-6.

17 Tartaglia M, Mehler EL, Goldberg R, Zampino G, Brunner HG, Kremer H, van der Burgt I, Crosby AH, lon A, Jeffery S, Kalidas K, Patton MA, Kucherlapati RS, Gelb BD. Mutations in PTPN1 1, encoding the protein tyrosine phosphatase SHP-2, cause Noonan syndrome. Nat Genet $2001 ; 29: 465-8$

18 Sarkozy A, Conti E, Seripa D, Digilio MC, Grifone N, Tandoi C, Fazio VM, Di Ciommo V, Marino B, Pizzuti A, Dallapiccola B. Correlation between PTPN1 
gene mutations and congenital heart defects in Noonan and LEOPARD syndromes. J Med Genet 2003;40:704-8.

19 Oda T, Elkahloun AG, Meltzer PS, Chandrasekharappa SC. Identification and cloning of the human homolog (JAG1) of the rat Jaggedl gene from the Alagille syndrome critical region at 20p12. Genomics 1997;43:376-9.
20 Li L, Krantz ID, Deng Y, Genin A, Banta AB, Collins CC, Qi M, Trask BJ, Kuo WL, Cochran J, Costa T, Pierpont ME, Rand EB, Piccoli DA, Hood L, Spinner NB. Alagille syndrome is caused by mutations in human Jagged1, which encodes a ligand for Notch1. Nat Genet 1997;16:243-51.

21 Krantz ID, Piccoli DA, Spinner NB. Clinical and molecular genetics of Alagille syndrome. Curr Opin Pediatr 1999;11:558-64. 